\title{
Influence of tree water potential in inducing flowering in Rhododendron arboreum in the central Himalayan region
}

\author{
Ashish Tewari, Jitendra Bhatt, \\ Amit Mittal
}

\begin{abstract}
Rise in temperature has been reported as the principal cause of variation in flowering phenology in several tree species around the globe. In this study, we hypothesized that not only temperature but also rainfall periodicity, soil moisture and the related changes of twig water potential $(\psi)$ in winter and early spring are important drivers of bud expansion and flowering in Rhododendron arboreum in central Himalayas. To this purpose, phenological and physiological variables (flowering time, flower bud size and twig water potential) were monitored over two years in a wild population of $R$. arboreum (Uttarakhand, India) and related with environmental variables (rainfall, soil moisture and temperature). Results showed that a rise in twig $\psi$ to $-0.7 \mathrm{MPa}$, one week after moderate winter precipitation resulted in flower bud enlargement. In both years flowering was triggered after twig $\psi$ reached the threshold of $-0.5 \mathrm{Mpa}$, though the starting date differed between years. Floral bud size was correlated positively with twig $\Psi(r=0.43$, df $=162, p<0.001)$ and soil moisture $(r=0.61, \mathrm{df}=71, \mathrm{p}<0.001)$, while temperature did not influence flower bud size, soil moisture and twig $\psi$. Flower bud size increment was related with increase in twig $\psi$ and soil moisture. Based on our results, we concluded that water availability plays an important role in inducing flowering in $R$. arboreum.
\end{abstract}

Keywords: Rhododendron, Global Warming, Flowering, Water Potential, Himalaya

may especially limit plant growth, in a highly seasonal climate. There is significant evidence that climate change has already induced changes in phenological phases of several species (Hughes 2000, Walther et al. 2002, Fitter \& Fitter 2002, Root et al. 2003, Gordo \& Sanz 2005, Menzel et al. 2006, Doi et al. 2010). Flowering time, its duration, and synchrony may affect the interactions of plants with their pollinators and seed dispersers (Aizen 2003). Phenological timing is important to the reproductive success and growth of plants (Menzel \& Fabian 1999, Chuine et al. 2000, Aizen 2003).

Water is one of the most important climatic factor affecting the growth and distribution of terrestrial plants. Flower bud expansion and shoot growth involving cell expansion are known to be inhibited by global warming (Singh \& Singh 2013) Erratic rainfall patterns and long droughts

$\square$ Department of Forestry and Environmental Science, Kumaun University, Nainital 263002 (India)

@ Ashish Tewari (atewari69@gmail.com)

Received: Dec 11, 2014 - Accepted: Dec 07, 2015

Citation: Tewari A, Bhatt J, Mittal A (2016). Influence of tree water potential in inducing flowering in Rhododendron arboreum in the central Himalayan region. iForest 9: 842-846. doi: 10.3832 /ifor1525-008 [online 2016-05-06]

Communicated by: Silvano Fares

even moderate water deficit (Borchert 1994a). Trees in seasonal climates often experience major water deficiency, and their physiology and phenology reflect the seasonality of moisture deficits (Singh et al. 2006).

The forests of Central Himalayas are dominated by oak and pine species (Singh \& Singh 1992). Water relations of these forests have been investigated by Zobel \& Singh (1995), Tewari (1998), Zobel et al. (2001), Poudyal et al. (2004) and Singh et al. (2006), while their phenology was studied by Ralhan et al. (1985), Pangtey et al. (1990), Rawal et al. (1991) and Negi (2006). Rhododendrons (Ericaceae) are under-canopy forest tree species widely distributed around the globe. There are about 1000 species of Rhododendron in the world, of which only 6 occur in the Indian central Himalayan region (Rawal et al. 1991). Rhododendron arboreum $\mathrm{Sm}$. is an early successional, evergreen species growing between $1200 \mathrm{~m}$ a.s.l. up to the timber line in the Pinus roxburghii and Quercus forests of the Himalayan region. R. arboreum is perhaps amongst the most studied species in the recent past due to evident changes in its flowering phenology, mainly attributed to global warming (Ranjitkar et al. 2012, Shah et al. 2014, Gaira et al. 2014).

In this study, the phenological changes of R. arboreum have been studied from a different perspective, particularly by considering the relationship between the period- 
Fig. 1 - Monthly variations in temperature and rainfall pattern during study period. Bar represent rainfall, lines with solid triangles minimum temperature and solid squares maximum temperature. Arrows indicate the experimental period.

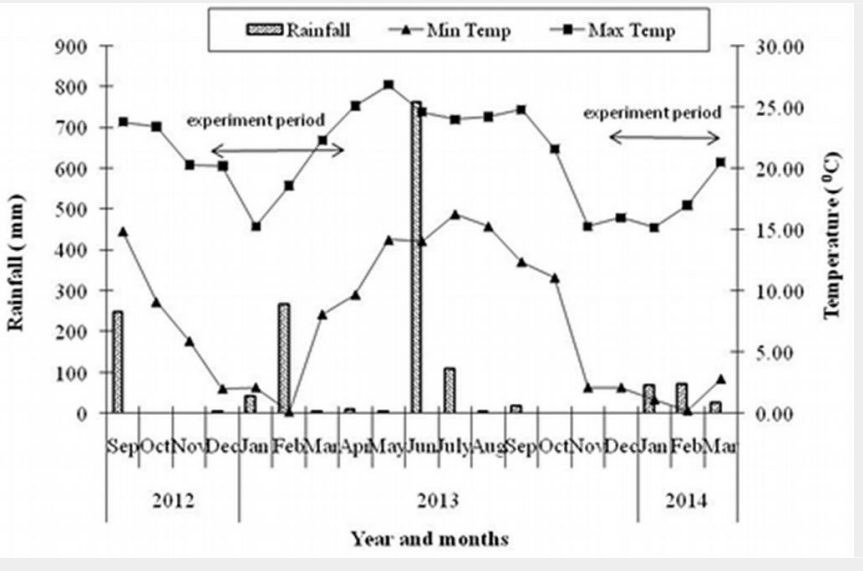

icity of rainfall and the twig water potential $(\psi)$. To our best knowledge, no study have related the effect of water availability on the physiology and phenology of this species in the Indian Himalayan region. We hypothesized that tree water potential and soil moisture could be important drivers of bud expansion and flowering in R. arboreum. We gathered data on temperature and rainfall, soil moisture, twig water potential, flower buds size and flowering time during the winter and early spring (the probable time of flowering in $R$. arboreum) over a two year period.

\section{Materials and methods}

The study area is located in the central Himalayan region (Uttarakhand province, India) between $29^{\circ} 23^{\prime} 15.1^{\prime \prime}$ and $29^{\circ} 23^{\prime}$ $17.5^{\prime \prime} \mathrm{N}$ of latitude and $79^{\circ} 30^{\prime} 31.0^{\prime \prime}$ and $79^{\circ}$

$30^{\prime} 38.3^{\prime \prime} \mathrm{E}$ of longitude, at an elevation ranging between 1760 and $1780 \mathrm{~m}$ a.s.I. Monsoon climate is prevalent in the study area. Meteorological data were collected from the Arya Bhatt Research Institute of Observational Sciences (ARIES), Nainital, located at a distance of $2 \mathrm{~km}$ from the study site at $1900 \mathrm{~m}$ a.s.l. Mean annual temperature is $14.8^{\circ} \mathrm{C}$, with a mean minimum temperature of the coldest month (January) of $8.2{ }^{\circ} \mathrm{C}$ and a mean maximum temperature of the warmest month (June) of $21.9^{\circ} \mathrm{C}$. The annual rainfall is $1267 \mathrm{~mm}$ on average (Fig. 1). The rocks of the study area are metamorphosed and soils are sandy in nature (Valdiya 1980, Bhatt \& Ram 2005). Anthropogenic disturbances in the study area are moderate and homogenous in terms of fire, lopping and grazing. Fire has not occurred in the area during the last 3-4

Tab. 1 - Main characteristics of tree species found in the studied transect.

\begin{tabular}{lcc}
\hline Species & Density $($ trees ha & -1 \\
\hline Rhododendron arboreum & 70 & Basal area $\left(\mathrm{m}^{2} \mathrm{ha}^{-1}\right)$ \\
Quercus leucotrichophora & 290 & 2.87 \\
Pinus roxburghii & 300 & 15.19 \\
Myrica esculenta & 110 & 15.17 \\
\hline
\end{tabular}

Fig. 2 - (a) Pre-dawn twig $\psi$ of R. arboreum in different weeks during flowering time in Yr1 and

Yr2. Each dot represents a week of measurement of predawn $\psi$. Yr1 denotes measurement weeks between Decem-

ber 2012 and March 2013 and Yr2 weeks between December 2013 and February 2014. D3 denotes Wk3 of December, J1 for Wk1 January, J3 for Wk3 January, F1 for Wk1 February, F3 for Wk3 February and $M_{1}$ for Wk1March. (b) Floral bud size

$\left(\mathrm{mm}^{2}\right)$ increment in R. arboreum at different weeks during flowering time in $\mathrm{Yr} 1$ and $\mathrm{Yr} 2$.

Each dot represents the week of bud size measurement.

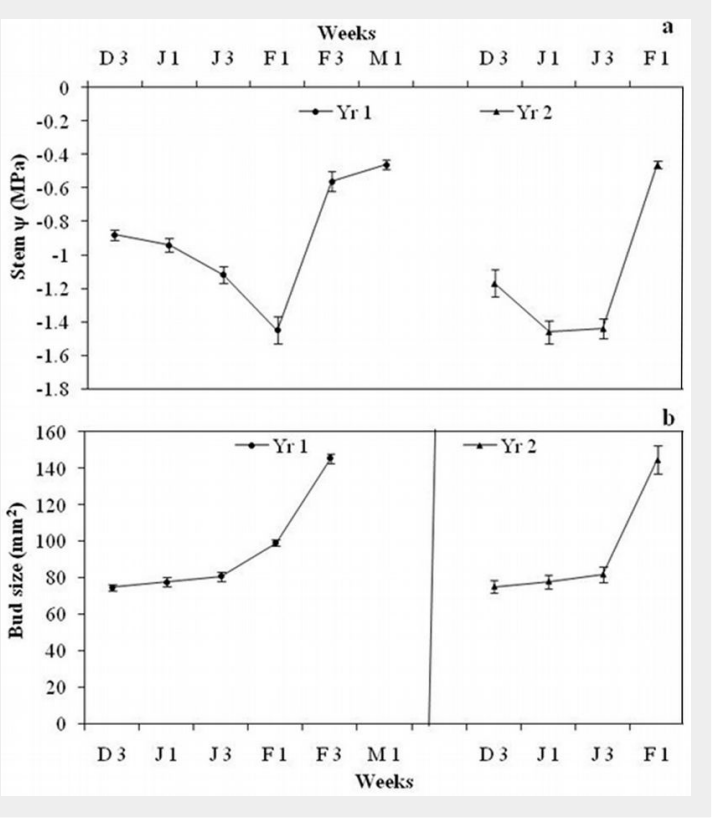

years and a herd of 4-5 cattle was seen grazing at the study site on every sampling date. However, no lopping scars were detected on branches of $R$. arboreum trees.

A transect of $400 \mathrm{~m}$ long and $50 \mathrm{~m}$ wide was established at the study site on a slope ranging between $15^{\circ}$ and $23^{\circ}$ with southeastern aspect. Tree layer vegetation was analyzed by placing twenty random quadrats of $10 \times 10 \mathrm{~m}$ (Saxena \& Singh 1982). Tree density was analyzed following the method proposed by Curtis \& McIntosh (1950) and the basal area was estimated as $c^{2} / 4 \pi$, where $c$ is circumference at breast height (1.37 $\mathrm{m}$ above the ground).

The survey on tree flowering phenology was conducted for two consecutive years (2012-2014) between December and March (when trees flower). Forty trees of R. arboreum (29\% of the whole population) were selected and marked within the transect: 13 at both ends of transect and 14 in the middle. All selected individuals were approximately of similar height (range: 4.0$6.7 \mathrm{~m}$ ) and diameter (range: $8 \cdot 3-10-7 \mathrm{~cm}$ ).

Data collection of flower bud size and twig water potential $(\psi)$ started in both years by the third week of December and completed with the opening of floral buds (March). Measurements were taken on 18 trees (13\% of the population) out of the 40 marked individuals of $R$. arboreum (6 each at base, middle and top of transect). Twig $\psi$ was measured using a pressure chamber (Model 1000, PMS Instrument Co., Albany, OR, USA - range 70 bars) by taking twig samples from 2-3 $\mathrm{m}$ above the ground. Predawn tree $\psi$ (05:30-07:00 am) was measured on $15-\mathrm{cm}$ long leaf bearing twig ( 3 twigs per tree - Zobel et al. 2001). Five floral buds per tree were labeled in December of both years to measure changes in bud size, estimated as the product of bud length and bud width $\left(\mathrm{mm}^{2}\right)$ measured with a digital caliper (Model CD-6"CS, accuracy +0.02mm - Mitutoyo Co., New Delhi, India). Pre-dawn twig $\psi$ and bud size were measured on the same day and tree. Six measurements between December 2012 and March 2013 (hereafter referred as Yr1) and four measurements between December 2013 and January 2014 (hereafter: Yr2) were taken, as flowering started earlier in Yr2. Flowering pattern was also observed from marked trees and observation on flowering was taken after a three-day interval from the opening of the first flowering bud. Bud opening was considered as the date when dormant flower bud was observed to be splitting (Bhatt \& Ram 2009). Result was expressed in terms of percentage of flowering trees. Soil moisture was estimated on a fresh weight basis in December, after the prolonged drought of 3 months and one week (hereafter: $\mathrm{Wk}$ ) after winter rainfall of January in both the years. After the end of the monsoon season (mid-September), there was very little $(<2 \mathrm{~cm})$ rainfall till January. To determine soil moisture, composite soil samples were prepared from three replicates, each of 10 
$\mathrm{g}$ from the top $30 \mathrm{~cm}$ layer, taken from below the canopy of each tree marked for twig $\psi$ measurement. Data were expressed in terms of mean and standard error of mean.

Paired $t$-test was used to test for difference between twig $\psi$ and floral bud increment among successive collection dates. Linear regression was applied to estimate the relationship between twig $\psi$, soil moisture and flower bud size; between soil moisture and flower bud size; between twig $\psi$ and flower bud size with maximum, minimum and mean temperature. Data analysis was carried out using the software Microsoft Excel ${ }^{\circledR}$. ANOVA was used to test the effect of twig $\psi$, temperature and their interaction on flower bud size change following Snedecor \& Cochran (1967).

\section{Results}

Density of R. arboreum was 70 trees hain the transect. Other associated species (all evergreen) were Pinus roxburghii, Quercus leucotrichophora and Myrica esculenta (Tab. 1). After the last monsoon rains of September, soils had become dry till December in both years, as no significant rainfall occurred during this period. Only sporadic rainfall $(<2 \mathrm{~cm})$, spread over a three-month period had occurred from September end to $\mathrm{Wk}_{3}$, January. Soil moisture in Wk3 December was $13.2 \pm 0.5 \%$ in $\mathrm{Yr} 1$ and $11.3 \pm 1.4 \%$ in Yr2. After the rainfall, soil moisture increased to $27.8 \pm 0.5 \%$ in Wk1 February $\mathrm{Yr} 1$ and $21.9 \pm 0.4 \%$ in $\mathrm{Wk}_{3}$ January Yrz up to $30 \mathrm{~cm}$ depth.

\section{Yr1 bud size and flowering}

Average pre-dawn twig $\psi$ was $-0.88 \pm$ 0.03 MPa during Wk3 December 2012 and further declined to $-1.45 \pm 0.08 \mathrm{MPa}$ in $\mathrm{Wk} 1$ February 2013. One week after rainfall, twig $\psi$ increased to $-0.56 \pm 0.06 \mathrm{MPa}$ in Wk3 February (Fig. 2a). The t-test indicated that twig $\psi$ started declining significantly after Wk1 January $(t=-3.99, \mathrm{df}=17, \mathrm{p}<$ $0.05)$ and continued to decline until Wk1 February, rising significantly in $\mathrm{Wk}_{3} 3$ February $(t=8.9, \mathrm{df}=17, \mathrm{p}<0.05)$, one week after the rainfall (Fig. 3). Moderate rainfall $(12.4 \mathrm{~cm})$ occurred 135 days after the end of monsoon season (last rainfall in September 2012), in Wk2 February. Weekly mean temperature ranged between 8.0 and 9.6 ${ }^{\circ} \mathrm{C}$ from December 2012 to February end 2013 and then rose rapidly (Fig. 3). Flower bud size increased from $74.6 \pm 1.6 \mathrm{~mm}^{2}$ in Wk3 December to $145.2 \pm 2.4 \mathrm{~mm}^{2}$ in $\mathrm{Wk}_{3}$ February (Fig. 2b). The $t$-test revealed that bud size remained more or less constant till Wk3 January, increased significantly between $W_{k} 3$ January and Wk1 February $(t$ $=4.8, \mathrm{df}=17, \mathrm{p}<0.05)$ and the increment was more rapid between Wk1 February and Wk3 February $(t=13.86, d f=17, p<0.05)$. Flowering started in $\mathrm{Wk}_{1}$ March and peaked ( $>90 \%$ trees had flowers) by $\mathrm{Wk}_{3}$ March.

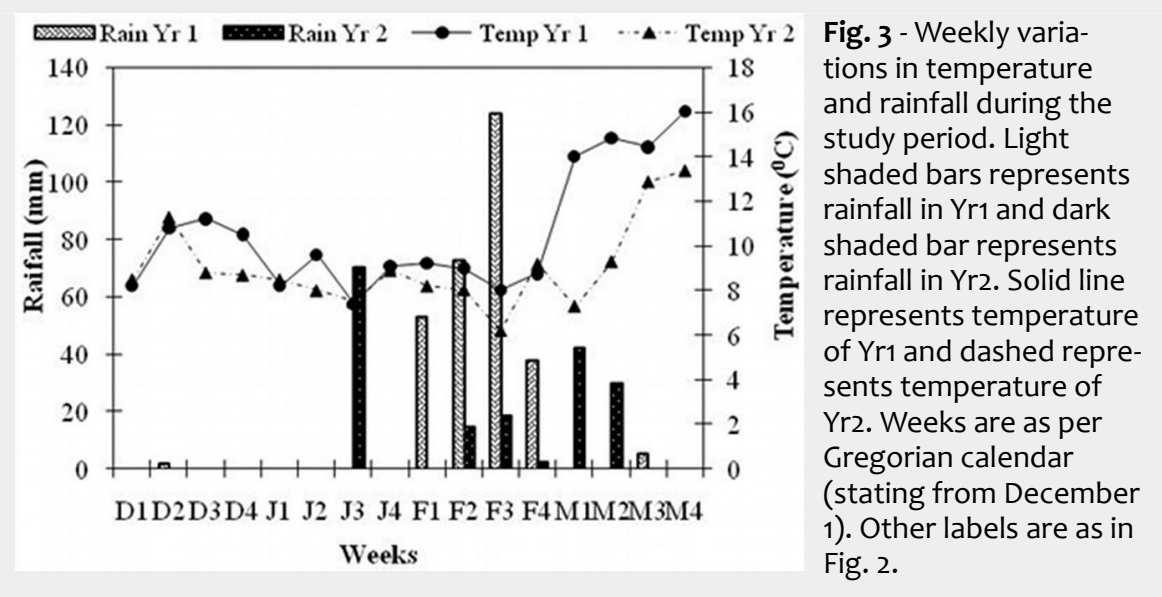

Yr2 bud size and flowering

Average pre-dawn twig $\psi$ was $-1.17 \pm 0.08 \quad 0.05)$ One $\mathrm{MPa}$ during $\mathrm{Wk} 3$ December 2013, then increased significantly to $-0.46 \pm 0.02 \mathrm{MPa}$ declined significantly to $-1.47 \pm 0.07 \mathrm{MPa}$ in in Wk1 February $(t=13.65, \mathrm{df}=17, \mathrm{p}<0.05-$

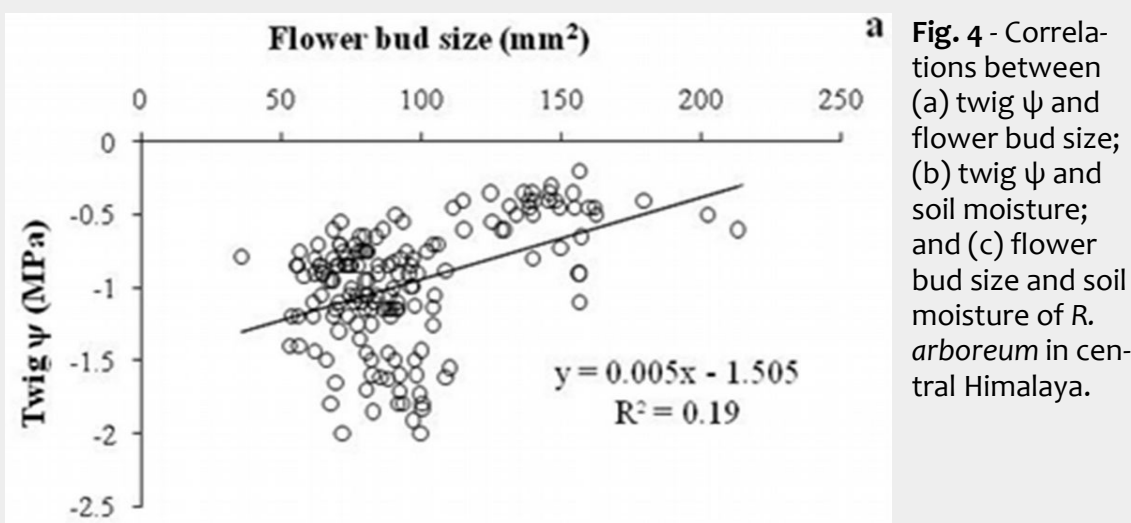

Soilmoisture $(\%)$

b
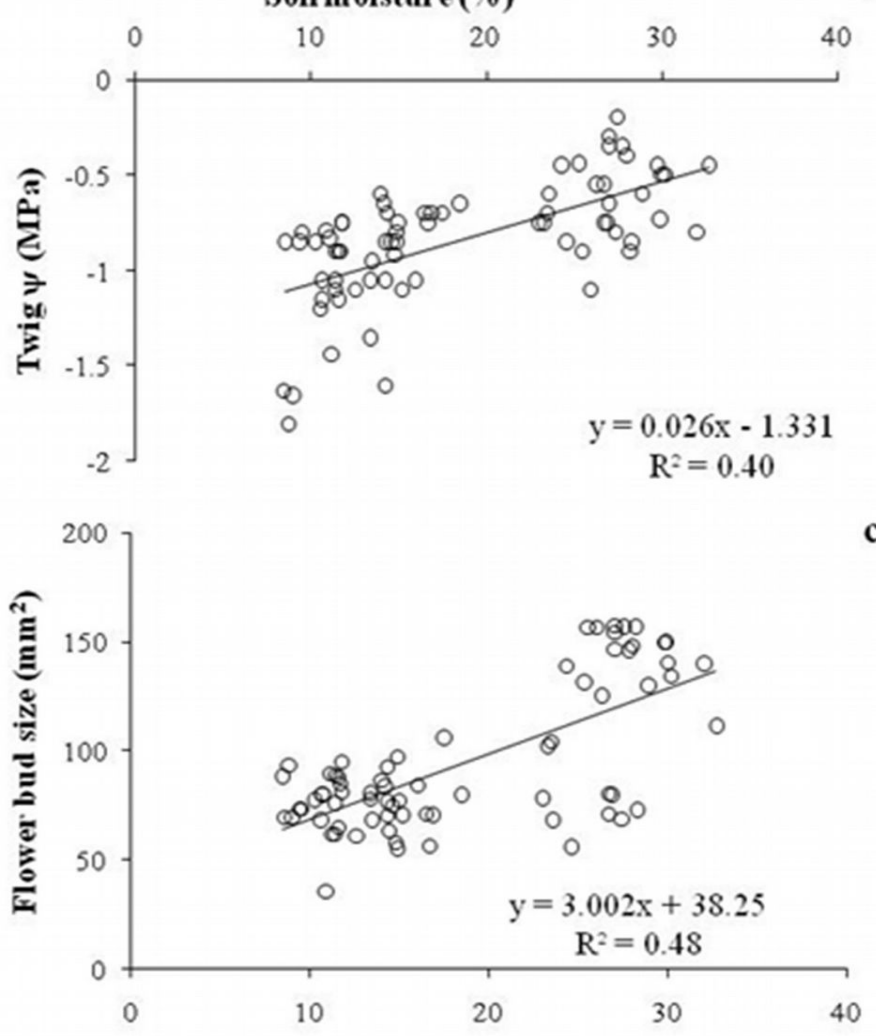

Soil moisture $(\%)$ 
Fig. 2a). Rainfall ( $>7 \mathrm{~cm}$ ) occurred 105 days after the end of monsoon in $\mathrm{Wk}_{3}$ January. Weekly mean temperature from December 2013 ranged between 8.0 and $9.3{ }^{\circ} \mathrm{C}$ until Wk2 of March 2014, and then rose sharply (Fig. 3). Floral bud size increased from 73.3 $\mathrm{mm}^{2}$ in $\mathrm{Wk}_{3}$ December to $144.5 \pm 7.6 \mathrm{~mm}^{2}$ in $\mathrm{Wk}_{1}$ February (Fig. 2b). The t-test revealed that bud size remained more or less constant up to $\mathrm{Wk}_{\mathrm{K}}$ January and then increased significantly $(t=6.53, d f=17, p<$ $0.05)$. Flowering started from the last week of January and peaked in Wk2 February, when more than $60 \%$ of trees had flowers.

No significant change in flower bud size was observed over the drought months, though buds started to expand in size following monsoon rains and after moderate precipitation in Wk1 February Yr1 and Wk3 January in Yr2. Bud size started to increase one week after rainfall in both years but the increment was more rapid in Yrz. ANOVA revealed a significant effect of twig $\psi$ on flower bud size $\left(F_{[5,126]}=60.79\right.$, $\mathrm{p}<0.0001)$, while the effect of temperature was not significant $\left(\mathrm{F}_{[5,126]}=0.51, \mathrm{p}=0.40\right)$. However, interaction of twig $\psi \times$ temperature was also significant $\left(\mathrm{F}_{[25,126]}=5.57, \mathrm{p}<\right.$ 0.01). Floral bud size and soil moisture were positively correlated with twig $\psi(r=$ $0.43, \mathrm{df}=162, \mathrm{p}<0.001$ and $\mathrm{r}=0.64, \mathrm{df}=71$, $\mathrm{p}<0.001$, respectively - Fig. 4a, Fig. 4b). Soil moisture was also positively correlated with flower bud size $(r=0.69, d f=71, p<$ 0.001 - Fig. 4C). Contrastingly, fortnightly maximum temperature $(r=0.03, d f=8, p>$ $0.05)$, minimum temperature $(r=0.41, \mathrm{df}=$ $8, p>0.05)$ and average temperature $(r=$ $0.05, d f=8, p>0.05$ ) were not significantly correlated with twig $\psi$. Similarly, none of the three parameters above were significantly correlated with flower bud size $(r=$ $0.45,0.2$ and 0.3 , respectively; $\mathrm{df}=8, \mathrm{p}>$ $0.05)$.

\section{Discussion}

In dry environments, heterogeneity and periodicity of water availability have been demonstrated as being crucial factor in determining the phenological rhythm of tree communities and populations (Konate et al. 1999, Seghieri \& Galle 1999). Twig $\psi$ plays an important role in bud emergence and expansion (Borchert 1994a). Indeed, Himalayan trees suffer significant water stress, though its intensity differs among different forest types (Zobel et al. 2001, Negi 2006). Twig $\psi$ of $R$. arboreum had declined to -1.5 MPa during the post monsoon period (between October and January) and started to increase 7-8 days after precipitation in both years. In Yr1 preciitation was $5.3 \mathrm{~cm}$ in Wk1 February and $7.0 \mathrm{~cm}$ in Yr2 at the start of Wk3 January (Fig. 3). Rainfall caused an increase of twig $\psi$ up to -0.7 MPa, determining a significant enlargement of floral bud size, and a further increase in twig $\psi$ to $-0.5 \mathrm{MPa}$ triggered flowering in R. arboreum (Fig. 4a). In tropical trees bud growth is blocked as long as stem $\psi$ is low, while flowering and bud break occurs only when the stem $\psi$ increases above -0.2 MPa (Borchert 1994a). In an artificial watering experiment in $\mathrm{Ta}$ bebwa ochracea, a tropical tree species, flower buds' size increased within 2 days of watering and were in full bloom after 5-7 days (Borchert 1994b). Some tree species are able to rehydrate active tissues before leaf flushing by withdrawing stored stem water (Poudyal et al. 2004). Significant increase in soil moisture percentage after precipitation is quite obvious and consistent with other studies. In a study on forests of Kumaun Himalaya, Tewari (1998) found that soil $\psi$ (60 $\mathrm{cm}$ depth) remains high up to autumn because of the continuing effect of the concentrated monsoon rainfall and declines rapidly in subsequent winters to an extent that trees may need to draw water from deeper soils.

Studies of Ranjitkar et al. (2012), Gaira et al. (2014) and Shah et al. (2014) focused on the role of global warming in inducing flowering in R. arboreum. Contrary to their findings, we did not observe the influence of temperature on bud size increment as well as twig $\psi$ in both years. This could be due to differences in elevation between the investigated sites. Indeed, our study site was located at the lower altitudinal range of $R$. arboreum where the temperature is sufficiently warm even during winters (6.0-8.0 ${ }^{\circ} \mathrm{C}$ on average) for flowering to occur after precipitation. Contrastingly, studies of Ranjitkar et al. (2012) and Shah et al. (2014) were carried out at higher elevation (above $2000 \mathrm{~m}$ a.s.l.) where temperature could be limiting. However, temperature data given in these studies have been collected from lower boundary of the species' altitudinal range (1700 and $2000 \mathrm{~m}$ ) and therefore should not fully represent the temperature of the entire elevation range. On-site meteorological data collection is very difficult in Himalayan forests, due to the intense human presence that hinder the possibility to leave the instruments in the field.

Temperature is considered as an important driver of plant phenology in temperate and boreal climate of Europe and North America (Parmensan \& Yohe 2003, Richardson et al. 2006, Vitasse et al. 2010, Way 2011), where soil water availability is not a limiting factor. Our study area lies in a warmer climate with a strongly seasonal precipitation and drought periods often occurring at the beginning of tree growth, thus representing a limiting factor for tree phenology.

Our results clearly revealed that flower bud enlargement occurred in both years only after winter precipitation, with trees flowering when predawn twig $\psi$ increases above the threshold of $-0.5 \mathrm{MPa}$. Variation in winter rainfall pattern together with marginal rise in minimum temperature during flowering time could be responsible for variation in flowering phenology between the years.

\section{Conclusions}

Global warming is thought to dramatically affect phenological shifts and flowering worldwide. The results of this study indicates that tree water potential and soil moisture have an important role in inducing bud enlargement and flowering in $R$. arboreum. Indeed, temperature alone did not trigger flowering in the studied species. Instead, our results indicate that the increase in soil moisture and twig water potential are a prerequisite for initiation of flower expansion in this species. However, studies based on more sites and years using on-site temperature data are required for better understanding the factors underlying the observed phenological changes in R. arboreum.

\section{Acknowledgements}

This study was funded by the Science and Engineering Research Board (SERB), New Delhi, India (Grant. No. SERB/SR/SO/PS/ 08/2010). AT and JB contributed to data analysis and drafted the manuscript. AM carried out field measurements. The authors thank the head of the Department of Forestry and Environmental Sciences for providing the departmental services. We are thankful to Prof. S. P. Singh, FNA, for the assistance in restructuring the manuscript and to Prof. Madhu Joshi, Department of English, KU Nainital (India) for language improvement. Finally, the authors are grateful to anonymous reviewers whose comments helped in improving the manuscript.

\section{References}

Aizen MA (2003). Influences of animal pollination and seed dispersal on winter flowering in a temperate mistletoe. Ecology 84: 2613-2627. doi: 10.1890/02-0521

Bhatt J, Ram J (2005). Seed characteristics and germination in Quercus leucotrichophora A. Camus along the elevational gradients in the Uttaranchal Himalaya. Bulletin of National School of Ecology 15: 207-213.

Bhatt J, Ram J (2009). Ecology and regeneration of Carpinus viminea: a lesser known tree species of the Himalaya. Indian Forester 135: 559570.

Borchert R (1994a). Soil and stem water storage determine phenology and distribution of tropical dry forest trees. Ecology 75: 1437-1449. - doi: $10.2307 / 1937467$

Borchert R (1994b). Induction of rehydration and bud break by irrigation or rain in deciduous trees of a tropical dry forest in Costa Rica. Trees 8: 198-204. - doi: 10.1007/BFo0196847

Chuine I, Belmonte J, Mignot A (2000). A modelling analysis of the genetic variation of phenology between tree populations. Journal of Ecology 88: 561-570. - doi: 10.1046/j.1365-2745.2000. 00468.x

Curtis JT, Mclntosh RP (1950). The interrelationship of certain analytic and synthetic characters. Ecology 31: 438-455.

Doi H, Takahashi M, Katano I (2010). Genetic diversity increases regional variation in phenological dates in response to climate change. 
Global Change Biology 16: 373-379. - doi: 10.1111/j.1365-2486.2009.01993.x

Fitter AH, Fitter RSR (2002). Rapid changes in flowering time in British plants. Science 296: 1689-1691. - doi: 10.1126/science.1071617

Gaira KS, Rawal RS, Rawat B, Bhatt ID (2014). Impact of climate change on the flowering of Rhododendron arboreum in central Himalaya, India. Current Science 106: 1735-1738.

Gordo O, Sanz JJ (2005). Phenology and climate change: a long-term study in a Mediterranean locality. Oecologia 146: 484-495. - doi: 10.1007/ s00442-005-0240-z

Hughes L (2000). Biological consequences of Global warming: is the signal already apparent. Trends in Ecology and Evolution 15: 56-61. - doi: 10.1016/S0169-5347(99)01764-4

IPCC (2014). Climate change 2014: impacts, adaptation, and vulnerability. Part A: Global and sectoral aspects. Working Group II contribution to AR 5, Cambridge University Press, Cambridge, UK and New York, USA, pp. 169-1131. [online] URL: http://www.ipcc.ch/report/ar5/wg2/

Kerr R (2004). Three degree of consequences: new focus. Science 305: 932-934. - doi: 10.1126/ science.305.5686.932

Konate S, Leroux X, Tessier D, Lepage M (1999). Influence of large termitaria on soil characteristics, soil wter regime and tree leaf shedding pattern in a West African savanna. Plant and Soil 206: 47-60. - doi: 10.1023/A:1004321023536

Menzel A, Fabian P (1999). Growing season extended in Europe. Nature 397: 659. - doi: 10.1038/17709

Menzel A, Sparks TH, Estrella N, Koch E, Aasa A, Ahas R, Alm-Kübler K, Bissolli P, Braslavska O, Briede A, Chmielewski FM, Crepinsek Z, Curnel Y, Dahl A, Defila C, Donnelly A, Filella Y, Jatczak K, Mage F, Mestre A, Nordli $\varnothing$, Peñuelas J, Pirinen $P$, Remisova $V$, Scheifinger $H$, Striz $M$, Susnik A, Van Vliet AJ, Wielgolaski FE, Zach S, Zust A (2006). European phenological response to climate change matches the warming pattern. Global Change Biology 12 (10): 1969-1976. - doi: 10.1111/j.1365-2486.2006.01193.x

Negi GCS (2006). Leaf and bud demography and shoot growth in evergreen and deciduous trees of central Himalaya, India. Trees 20: 416-429. doi: 10.1007/s00468-006-0056-4
Pangtey YPS, Rawal RS, Bankoti NS, Samant SS (1990). Phenology of high altitude plants of Kumaun in central Himalaya, India. International. Journal of Biometeorology 34: 122-127. doi: 10.1007/BF01093457

Parmensan C, Yohe G (2003). A globally coherent fingerprint of climate change impacts across natural ecosystems. Nature 421: 37-42. - doi: 10.1038/nature01286

Poudyal K, Jha PK, Zobel DB, Thapa CB (2004). Patterns of leaf conductance and water potential of five Himalayan tree species. Tree Physiology 24: 689-699. - doi: 10.1093/treephys/24.6. 689

Ralhan PK, Khanna RK, Singh SP, Singh JS (1985). Phenological characteristics of the tree layer of Kumaun Himalayan forests. Vegetatio 60: 91101. - doi: 10.1007/BFoo040351

Ranjitkar S, Luedeling E, Shrestha KK, Guan K, Xu $J$ (2012). Flowering phenology of tree Rhododendron along an elevation gradient in two sites in the eastern Himalaya. International Journal of Biometeorology 57 (2): 225-240. doi: 10.1007/500484-012-05-0548-4

Rawal RS, Bankoti NS, Smanat SS, Pangti YPS (1991). Phenology of tree layer species from the timber line around Kumaun in central Himalaya, India. Vegetatio 93: 109-118. - doi: 10.1007/BFo0033205

Richardson AD, Bailey AS, Denny EG, Martin CW, O'Keefe J (2006). Phenology of a northern hardwood canopy. Global Change Biology 12: 1174-1188. - doi: 10.1111/j.1365-2486.2006.01164.x Root TL, Price JT, Hall KR, Schneider SH, Rosenzweig C, Punds JA (2003). Fingerprints of global warming on wild animals and plants. Nature 421: 57-60. - doi: 10.1038/nature01333

Saxena AK, Singh JS (1982). A phytosociological analysis of woody species in forest communities of a part of Kumaun Himalaya. Vegetatio 50: 3-22. - doi: 10.1007/BF00120674

Seghieri J, Galle S (1999). Run-on contribution to a sahelian two-phase mosaic system: soil water regime and vegetation life cycle. Acta Oecologia 20: 209-218. - doi: 10.1016/S1146-609X(99) 80033-2

Shah S, Verma A, Tewari A (2014). Timing of shift in phonological events in Rhododendron arboreum Sm. Influenced by climatic irregularities in
Kumaun region of central Himalaya. Global Journal of Scientific Research 2: 59-59.

Singh JS, Singh SP (1992). Forests of Himalaya: structure, functioning and impact of man. Gyanodaya Prakashan, Nainital, India, pp. 294.

Singh SP, Singh V (2013). Certain observed and likely ecological responses to climate change in central Himalayas. Climate change and Environmental Sustainability 1: 73-80. - doi: 10.5958/j.23 20-6511.1.1.007

Singh SP, Zobel DB, Garkoti SC, Tewari A, Negi CMS (2006). Pattern in water relations of central Himalayan trees. Tropical Ecology 47: 159182.

Snedecor GW, Cochran WG (1967). Statistical methods. Oxford and IBH Publishing Co., New Delhi, India, pp. 593.

Tewari A (1998). Timing of drought: Effects of water relation of certain major forest types of lower and middle central Himalaya. PhD Thesis, Department of Forestry, Kumaun University, Nainital, India, pp. 133.

Valdiya KS (1980). Startigraphic scheme of the sedimentary units of the Kumaun lesser Himalaya. In: "Stratigraphy and correlation of the lesser Himalayan formation" (Valdiya KS, Bhatiya SB eds). Hindustan publishing corporation, Delhi, India, pp. 7-48.

Vitasse Y, Bresson CC, Kremer A, Michalet R, Delzon S (2010). Quantifying phenological plasticity to temperature in two temperate tree species. Functional Ecology 24: 1211-1218. - doi: 10.1111/j.1365-2435.2010.01748.x

Walther GR, Post E, Conrey P, Menzel A, Parmensan C, Beebee TJC, Fromentin JM, Hoegh-Goldberg $\mathrm{O}$, Bairlein $\mathrm{F}$ (2002). Ecological responses to current climate change. Nature 416: 389-395. - doi: $10.1038 / 416389 a$

Way DA (2011). Tree phenology responses to warming: spring forward, fall back? Tree Physiology 31: 469-471. - doi: 10.1093/treephys/tpr 044

Zobel DB, Garkoti SC, Singh SP, Tewari A, Negi CMS (2001). Patterns of water potential among forest types of the central Himalaya. Current Science 80: 774-779.

Zobel DB, Singh SP (1995). Tree water relations along the vegetational gradient in the Himalayas. Current Science 68: 742-745. 